Vol.10, Issue 1, pp. 49-63, 2022

Online ISSN: 2054-636X (Online)

Print ISSN: 2054-6351(Print)

\title{
THE EXTENT TO WHICH THE ISLAMIC JURISPRUDENCE BRANCH OF CONTEMPORARY WOMEN'S ISSUES AND RULINGS, IS INCLUDED IN THE CURRICULUM OF RELIGION AND ISLAMIC EDUCATION FOR THE SECONDARY STAGE
}

\author{
Faida Abu Much \\ Lecturer in Islamic Studies and Pedagogical Instructor - Al-Qasemi Academic College of \\ Education.

\section{Taghread Keadan} \\ Department Chair Al-Qasemi Academic College of Education, Department of Islamic \\ Studies -Master's degree.
}

\begin{abstract}
The study aimed to reveal the extent to which the Islamic jurisprudence branch included the issues and provisions of contemporary women in the curriculum of Islamic education for the secondary stage. It also aimed to explain what is meant by Islamic education and its characteristics in the school curricula, and to identify the role of the Islamic education curriculum for the secondary stage in building the student's personality and introducing her to the issues and provisions that concern her at this stage. The two researchers used the content analysis method because it is the most appropriate approach for the subject of the study and the most appropriate to achieve its objectives. The study tool was limited to analyzing the Islamic jurisprudence branch in the Islamic education curriculum for the secondary stage that is approved for teaching in secondary schools in the Arab community in Israel. It is clear from the results of the analysis that the Islamic jurisprudence branch ignored most Issues and rulings related to contemporary women. Its goals and contents have focused on the field of worship without other fields of Islamic jurisprudence such as communications and personal status, and on one aspect of worship represented in the ritual appearance without the social and cosmic appearance. These results confirm the weakness of the design of the Islamic jurisprudence branch in the Islamic education curriculum for the secondary stage and states how it lacks the legal issues and rulings that the student needs to know.
\end{abstract}

KEYWORDS: Islamic education, secondary school, Islamic jurisprudence, contemporary issues, women's provisions.

\section{INTRODUCTION}

The strength, cohesion, and safety from pests in the Arab community in Israel requires the upbringing of a generation of qualified young women based on the pillars of awareness

ECRTD-UK https://www.eajournals.org/

ULR: https://doi.org/10.37745/bje.2013 
and virtues, capable of working, producing, and standing up to the challenges that this society faces at this sensitive stage in our history. The woman is given care and attention, as a necessity for her individual interest, with the energies and preparations she possesses, and as a social and economic necessity . ${ }^{1}$

The secondary stage is considered the top of the pyramid in the education and upbringing of this generation. Attention to secondary education has become a necessity for civilized development towards the new century. Civilization is the product of reason, and progress is the product of thought. (Mualem, 2008). Therefore, it is the responsibility of this stage to enlighten the learner about matters related to their private and public life, and to take care of them and guiding them educationally, socially and intellectually, by knowing the characteristics of their growth and needs, and fulfilling the demands of these characteristics and needs (Al-Jaafari, 2014).

Islamic education includes an integrated educational approach to prepare women for the purpose of building their personality and building society on sound scientific foundations. One of the most important branches of this curriculum is the branch of Islamic jurisprudence, which is concerned with self-knowledge of what one has and what owes; where its provisions are distributed in two areas: worship and communications. Observing the societies that have implemented this educational approach one sees its great role and its clear contribution to producing generations of women with a great deal of scientific knowledge and community participation, with a great deal of moral commitment in behavior and treatment.

A school is one of the most important institutions responsible for social upbringing, in which the individual learns, crystallizes personality, and forns awareness towards the issues of life and the developments that occur to them. The school's tool for upbringing and instilling values is the school curriculum; where these curricula include the most important issues and topics that refine the student's personality, gain the majority of values, determine their trends and practices, and qualify them to deal with all that they will face in the future. Therefore, this study focused on issues and provisions that concern women in the Islamic jurisprudence branch of the curriculum of religion and Islamic education for the Secondary stage in the schools of the Arab community in Israel.

\section{The Problem of the Study}

It has been noticed recently that there has been an increase in attention to women's issues through their role in society and participation in the political and economic process. In addition to the need to rehabilitate them to obtain their full rights without any decrease in order to equalize them with men in rights and duties as long as they do not conflict with

1 .For the characteristics of the strong and virtuous woman model, see: Al-Kilani, Majid Arsan. (2005). An open letter to the Muslim girl in the era of globalization, 1st Edition, Dar Al-Qalam: Dubai, p. 21 and beyond.

ECRTD-UK https://www.eajournals.org/

ULR: https://doi.org/10.37745/bje.2013 
Vol.10, Issue 1, pp. 49-63, 2022

Online ISSN: 2054-636X (Online)

Print ISSN: 2054-6351(Print)

the provisions of the Islamic religion and are not considered a violation of custom. Therefore, the school curricula in general and the curriculum of religion and Islamic education in particular have a major role in focusing on the most important topics that contribute to the formation of sufficient awareness of the student to deal with various issues in the post-school stage. From this point of view, the problem of this study crystallizes in revealing the extent to which the branch of the Islamic jurisprudence in the curriculum of religion and Islamic education for the secondary stage includes contemporary women's issues and rulings.

\section{The questions of the Study:}

The study is based on the following main question:

To what extent does the Islamic jurisprudence branch in the curriculum of religion and Islamic education for the secondary stage, include contemporary women's issues and rulings?

The following questions arise from it:

1. What are the specific objectives of the Islamic jurisprudence branch in the curriculum of religion and Islamic education for the secondary stage?

2. What are the prescribed topics in the Islamic jurisprudence branch in the curriculum of religion and Islamic education for the secondary stage?

1. What are the expected achievements of students related to the specific objectives of the Islamic Fiqh Branch in the Religion and Islamic Education Curriculum for the secondary stage?

\section{The importance of studying}

The importance of this study lies in the analysis and critique of the objectives and content of the Islamic jurisprudence branch in the curriculum of religion and Islamic education for the secondary stage in Arab schools in Israel. In addition to its relevance to the Islamic education curriculum according to its philosophy of education, its contribution to the preparation of contemporary Muslim women in Arab society in Israel, and its inclusion of contemporary issues and associated provisions

\section{Objectives of the study}

This study aims to reveal the extent to which the Islamic jurisprudence branch in the curriculum of religion and Islamic education for the secondary stage includes contemporary women's issues and rulings, and aims at the following: 
1. Explaining what is meant by Islamic education and its characteristics in the school curricula.

2. Knowing the specific objectives of the Islamic jurisprudence branch and recognizing the expected achievements of students of the curriculum of religion and Islamic education at the secondary stage.

3. Recognizing the role of the Islamic jurisprudence branch in the curriculum of religion and Islamic education for the secondary stage and knowing its role in refining the personality of the students and introducing them to the issues and provisions that apply to their concern.

\section{STUDY METHODOLOGY}

The study used the content analysis and criticism method because it is the most appropriate method for the subject of the study and the most appropriate to achieve its objectives. The two researchers conducted a survey and analysis of the objectives and contents of the Islamic jurisprudence branch in the curriculum of religion and Islamic education to reveal the issues and rulings of contemporary women.

\section{Study tool:}

The study tool was formed by relying on theoretical literature that is concerned with the subject of Islamic jurisprudence, and considering the various fields that it includes, namely: the field of worship, which is represented by three aspects: ritual, social and cosmic, and the field of communications, from which it is branched: personal status, economic dealings, constitutional provisions and others. (Al-Bagha, 2007; Al-Kilani, 2006).

\section{THEORETICAL LITERATURE AND PREVIOUS STUDIES}

\section{First, the theoretical literature}

The Arab-Muslim community in Israel has witnessed a number of social, cultural and economic transformations in various areas of life in this era. This requires a direction towards a constructive reform in the field of education, mainly represented in the educational institutions of this society. There is a need to revise the educational curricula, including the Islamic education curriculum, with the aim of graduating a female learner who possesses a balance of knowledge in the field of legal, linguistic and literary sciences. This will qualify her to understand, represent and analyze the various components of Islamic education, possessing the tools to deal with types of legal and educational discourse, being capable of knowing herself, the rights of others, and crystallize her in her relationships with others. The educational curriculum is a tool of enlightenment and 
illumination that reminds the learner of a sense of belonging to the group through a balanced tripartite perspective in which the goals of the individual, society and knowledge converge, and contribute to the formation of awareness to harness knowledge in building society through self-realization (Al-Khalidi, 2004).

\section{The concept of education in Islam and the characteristics of Islamic education:}

Education in Islam is defined as: "Preparing Muslim individuals to produce knowledge that is characterized by authenticity and modernity in the various fields of life. In order to prepare them to improve, master administratively, intellectually and practicing, using this knowledge, in the individuals' and groups' lives, in the light of their relationships with the Creator, the universe, mankind and the afterlife" (Al-Kilani, 2005 ). Islamic education is characterized by its broadness and comprehensiveness. It meets the needs and requirements of individuals and society, because it includes broad outlines and sound principles of cognitive dimensions and valuable educational contents. It is also characterized by flexibility in terms of its connection with the course of reality and the development of life. It is a sort of education that is capable of generating ideas, liberating issues, renewing curricula in research and others to improve science and reviewing the old thoughts in various fields. (Al-Salihi, 2009).

Islamic education aims to achieve a balance among all aspects of personality. Knowledge and the representation of values lead to application and behavior change. Islamic education combines the indoctrination of knowledge, skill training, and value building; to move the learner, after taking positive attitudes, towards the right of God Almighty, the right of himself and the right of others, to the initiative and action to achieve public and private benefit. Imam Al-Ghazali says: "Attaining benefit and repelling harm are the purposes of the truth and the goodness of creation is in protecting their purposes. However, we mean by interest based on the Sharia's intentions of creation as five: that is to preserve their religion, their lives, their minds, their offspring and their wealth" (Al-Ghazali, 1993, p. 174).

The ultimate goal of Islamic education is "Achieving servitude to God Almighty in the individual and social life of man" (Al-Nahlawi, 2010). The Noble Qur'an, the noble hadith, jurisprudence, the biography of the Prophet and the purification of the souls, where the terms of these branches was developed to educate the learner's personality in all its psychological, social, spiritual, behavioral and mental aspects, to be a worshiper of God in all the affairs of their life. (Shatiwa et al., 2011), and it is explained in the objectives of the general Islamic education curriculum, and in the specific objectives of each stage of education. 
Vol.10, Issue 1, pp. 49-63, 2022

Online ISSN: 2054-636X (Online)

Print ISSN: 2054-6351(Print)

Islamic jurisprudence in the Islamic education curriculum and the source of its objectives

Islamic jurisprudence is one of the branches of the Islamic education curriculum prescribed for students at all academic levels, and jurisprudence is "knowledge of practical legal rulings deduced from detailed evidence" (Samak, 2006). It is assumed that the branch of Islamic jurisprudence in the curriculum of Islamic education for the secondary stage represents an important tributary of culture and knowledge, as it reflects the principles, values and ideals brought by Islamic legislation, and translates them into procedural behavior to prepare the individual and build their personality based on comprehensiveness, balance, realism and flexibility. (Al-Badina, 2010).

Al-Kilani (2006) believes that "the concept of worship in Islamic education includes three aspects: a ritual appearance, a social appearance, and a cosmic appearance." The ritual appearance is represented in the rituals and practices in which the Creator is worshiped, and its application requires familiarizing the learners with the details of religious rituals and practices, and training them to perform them in the light of Islamic directives related to this. As for the social aspect, its subject is culture, values, customs, traditions, and systems. Its application requires introducing learners to the network of social relations starting from their family circle and ending with their human circle, training them its practices, and studying the practices of others in the past and present; to find out the results and fruits, positive and negative.

As for the cosmic aspect of worship: its subject is the natural sciences that provide the Muslim scientist the access to horizons highlighting the current miracles and their proofs and provide evidence that reveal the greatness of God's work and power. In addition, they convince the learners of the new generations of the obligation to love the Creator fully, to obey Him in complete obedience, and to apply this aspect of worship. Applying this worship aspect requires education to enter the learners into the laboratory of the universe; to introduce them to it, and direct them to discover the laws that regulate living organisms and nature, and to discover their characteristics. (Al-Kilani, 2006).

As for the provisions on communications, they varied in the modern era to include the following provisions: personal status provisions, civil and financial provisions, pleadings provisions, constitutional provisions, and international provisions. (Al-Bagha, 2007).

Islamic jurisprudence in the Islamic education curriculum and the extent to which it includes contemporary women's issues and rulings:

Islamic jurisprudence contains many rulings that were specific to women and distinguished them from men, and the Almighty's saying: \{And the male is not like the female\} (Al 
Imran: 36) confirming this particularity, and based on it, both the man and the woman had a job worthy for them in the construction of the earth. From this point of view comes the importance of enriching the Islamic jurisprudence branch in the Islamic education curriculum in a way that suits the specificity of women. As the content of this branch should include contemporary issues that are related to the student, and are related to her life, so that she accepts her studies and feels its importance in life. (Ashtiwa, Abu Rizk, Odeh, 2011).

Contemporary women's issues and rulings are distributed to all areas that are related to them. Whether they are in the field of worship, communications, personal status, or political and international relations, which occurred as a result of the great social, economic and scientific changes, and the tremendous development in this era that calls for attention and conscious planning from those in charge to work on embracing the curricula of Islamic education. In order to work on accommodating the most important of these issues and developments and presenting them in the curricula of Islamic education in a modern way that is in line with the current reality of changes, and in a manner that suits the girl at this age.

\section{Second: previous studies}

Al-Assali and others (2019) conducted a study that aimed to analyze the content of the basic school books from the first to the ninth grade of Arabic language, mathematics, Islamic education, national and social education, science and life in the Palestinian curricula. It also aimed to reveal the extent to which it observes the system of the social gender between males and females, and in the distribution of professions between males and females. The study used the content analysis method by analyzing the content of the mentioned curricula, and the study concluded that some topics of the Islamic education curriculum may be sensitive according to gender differences.

Shain (Sahin, 2018) conducted a study aimed at focusing on the Islamic education curriculum and its inclusion of central issues related to Islamic values and concepts and the position of women in Western, secular and liberal studies. The study succeeded to remove the contradiction between the mental image of women in the Western mentality, and to clarify her position in the educational and Islamic heritage.

As for Al-Rifai study (2016), it aimed to analyze the content of jurisprudence books for the secondary stage in the Kingdom of Saudi Arabia and measure the extent to which they include issues of women's jurisprudence. The study used the descriptive-analytical approach, where the researcher made a list of issues of women's jurisprudence, and built an analysis card on its basis. The researcher analyzed the book of jurisprudence for the second grade of secondary school, for issues of jurisprudence of women. The results 
showed weakness in the content of the third secondary grade book for women's jurisprudence issues.

While the study of Al Raqab (2015) aimed to know the results of educational research for master's and doctoral theses in the content of the Islamic religious education curriculum, and to know the availability of educational research results for master's and doctoral theses in the content of the Islamic education curriculum in the branches of Islamic education in Palestine. The study focused on the axis of Islamic jurisprudence in order to Know the issues that the Islamic education curriculum focuses on. The results of the study concluded that teaching strategies and educational activities in the Islamic education curriculum are available and that the curriculum does not encourage the use of modern systems. They also showed that there is a weakness in the field of assessment as the assessment did not focus on the practical aspect of life in the tests and did not specify a comprehensive evaluation for each unit of Islamic education

The study of Al-Tamimi and Khawaldeh (2013) aimed to investigate women's issues in Islamic education books for the upper basic stage in Jordan, and its sample consisted of seventh, eighth, ninth and tenth grade books. The study concluded that the studied books focused on issues of concern to women, including humanitarian, social, economic and political issues. In addition to the legal issues related to women. As for Abdel-Aal's study (2011), it aimed to reveal the most prominent topics that pertain to women, including the topics of sexual education urged by the Holy Qur'an and the Prophet's Sunnah, by building a list of the most important sexual education topics, and identifying the extent to which Islamic education books in the secondary stage contain sexual education topics. The study highlights the importance of taking care of the controls of sexual education in Islam and benefiting adolescents in education, the importance of the adolescence stage and the necessity of helping and guiding adolescents in the subject of sexual education.

Bowen's study (2004) aimed to explore the roles of women during the American Revolution, the Civil War and the First World War in the history curriculum for the secondary stage. The study used the content analysis method. The results of the study concluded that books that traditionally presented women's roles; as women do not play a valuable role in the texts that are mentioned on the subject, although in fact women played an important role during these events. The study of Özdoğru et al. (2002) aimed to analyze the roles of women in primary school textbooks in Turkish schools, and its sample consisted of Turkish language books and life studies for the third grade. In school or in the family environment, the study stated that the issues faced by women lie in absolute inequality with men, and limiting them to domestic tasks and childcare. 
To achieve the study's goal in revealing the extent to which the Islamic jurisprudence branch includes contemporary women's issues, and its role in preparing them by answering the main question, the objectives and content of Islamic jurisprudence in the curriculum of religion and Islamic education for the secondary stage were analyzed. (Ministry of Education, 2016), the results showed the following:

Table No. (1) The results of analyzing the specific objectives of the branch of Islamic jurisprudence and determining the subject assigned to it in the curriculum of religion and Islamic education for the secondary stage:

\begin{tabular}{|l|l|}
\hline $\begin{array}{l}\text { The specific goal in the branch of Islamic } \\
\text { jurisprudence } \text { for the secondary stage }\end{array}$ & $\begin{array}{c}\text { The subject in the curriculum of religion and Islamic } \\
\text { education for the secondary stage }\end{array}$ \\
\hline $\begin{array}{l}\text { 1. Knowing the importance of the intention and its } \\
\text { impact on worship. }\end{array}$ & - Worship \\
\hline $\begin{array}{l}\text { 2. Knowing the importance of ablution, how to perform } \\
\text { it, and its conditions and invalidities. }\end{array}$ & - Worship \\
\hline $\begin{array}{l}\text { 3. Understand how to perform prayer, the conditions for } \\
\text { its validity, its pillars, its Sunna, its etiquette, its } \\
\text { requirements, and its types. }\end{array}$ & - Worship \\
\hline $\begin{array}{l}\text { 4. Getting acquainted with the concept of fasting, its } \\
\text { pillars, nullifiers, excuses, expiation and/or making up } \\
\text { for it. }\end{array}$ & - Worship \\
\hline $\begin{array}{l}\text { 5. Recognizing the concept of zakat, to whom it is given, } \\
\text { and the money that must be paid in it. }\end{array}$ & - Worship \\
\hline 6. Ihram and the temporal and spatial (Miqat) for Hajj. & - Worship \\
\hline 7. Knowledge of the provisions of dress and adornment & 3 \\
\hline $\begin{array}{l}\text { 8. Linking the effect of worship to public behavior and } \\
\text { morals. }\end{array}$ & - Worship \\
\hline No specific objective has been set related to this content & The concept of jurisprudence and its sources. \\
\hline No specific goal has been set related to this content & Mandatory provisions \\
\hline No specific objective has been set related to this content & - Optional subject (engagement and marriage) \\
\hline No specific objective has been set related to this content & - Elective subject (Purposes of Sharia) \\
\hline
\end{tabular}

${ }^{2}$ The specific goal: is the goal that has been formulated in the Islamic education curriculum related to one of the established topics of Islamic jurisprudence.

3 See the educational curriculum: Religion and Islamic Education, Ministry of Education, Educational Secretariat, Heritage Department, Jerusalem, 2016, pp. 17-18. 
By reading Table (No.1), it becomes clear that there are eight specific objectives for the branch of Islamic jurisprudence in the Islamic education curriculum for the secondary stage, all these objectives are related to the subject of worship, and they are distributed on the following topics: intention, ablution, prayer, fasting, zakat, (Hajj) pilgrimage, and dress and adornment. The results also indicate the inclusion of four topics scheduled for secondary school students, namely: the concept of jurisprudence and its sources, mandated provisions, engagement and marriage, and the purposes of legislation; without specifying specific goals in the curriculum.

Noting that two of these topics were classified as optional topics - engagement and marriage, and the purposes of legislation - which means that it is not necessary for the student to study them at this stage.

In Table (No. 2), the results of analyzing the specific objectives of the Islamic jurisprudence branch and the expected achievements of students in the religion and Islamic education curriculum for the secondary stage:

\begin{tabular}{|l|l|}
\hline $\begin{array}{l}\text { The specific goal in the branch of Islamic } \\
\text { jurisprudence for the secondary stage }\end{array}$ & ' Expected achievements of high school students \\
\hline $\begin{array}{l}\text { 1. Knowing the importance of the intention and its } \\
\text { impact on worship. }\end{array}$ & - \\
\hline $\begin{array}{l}\text { 2. Knowing the importance of ablution, how to perform } \\
\text { it, its conditions, and what invalidates it. }\end{array}$ & $\begin{array}{l}\text { Knowing the importance of ablution, how to perform it, } \\
\text { its conditions, and its invalidities. }\end{array}$ \\
\hline $\begin{array}{l}\text { 3. Understand how to perform prayer, the conditions for } \\
\text { its validity, its pillars, its Sunna, its etiquette, its } \\
\text { requirements, and its types. }\end{array}$ & $\begin{array}{l}\text { - Getting to know some types of prayer (the obligation } \\
\text { and the Sunnah) and their status among the acts of } \\
\text { worship. }\end{array}$ \\
\hline $\begin{array}{l}\text { 4. Getting acquainted with the concept of fasting, its } \\
\text { pillars, nullifiers, excuses, expiation and/or making up } \\
\text { for it. }\end{array}$ & $\begin{array}{l}\text { Deduce the rulings of fasting, its virtues and its medical } \\
\text { benefits. }\end{array}$ \\
\hline $\begin{array}{l}\text { 5. Familiarize yourself with the concept of zakat, to } \\
\text { whom it is given, and the money that must be paid in it. }\end{array}$ & $\begin{array}{l}\text { Knowing the money on which zakat is due, its quorum } \\
\text { and amount. }\end{array}$ \\
\hline 6. Ihram and the temporal and spatial miqat for Hajj. & Learn about Hajj and Umrah. \\
\hline \begin{tabular}{l} 
7. Knowledge of the provisions of dress and adornment. \\
\hline
\end{tabular} & \begin{tabular}{l}
--------- \\
\hline
\end{tabular} \\
\hline
\end{tabular}

4 Expected achievement of students: It indicates the main topic and sub-topics that should be included in the content of the textbook (or in other words: the titles of the lessons in the textbook). 
Vol.10, Issue 1, pp. 49-63, 2022

Online ISSN: 2054-636X (Online)

Print ISSN: 2054-6351(Print)

\begin{tabular}{|l|l|}
\hline $\begin{array}{l}\text { 8. Linking the effect of worship to public behavior and } \\
\text { morals. }\end{array}$ & $\begin{array}{l}\text { - Concluding the role of zakat in solving society's } \\
\text { problems (economic, social and psychological). }\end{array}$ \\
\hline $\begin{array}{l}\text { There is no specific objective associated with these } \\
\text { achievements }\end{array}$ & $\begin{array}{l}\text { Clarify the concept of Fiqh (jurisprudence), } \\
\text { linguistically and idiomatically. }\end{array}$ \\
\hline $\begin{array}{l}\text { There is no specific objective associated with these } \\
\text { achievements }\end{array}$ & $\begin{array}{l}\text { Getting to know the sources of Islamic jurisprudence } \\
\text { and legislation. }\end{array}$ \\
\hline $\begin{array}{l}\text { There is no specific objective associated with these } \\
\text { achievements }\end{array}$ & Analyzing the concept of the legal mandate. \\
\hline $\begin{array}{l}\text { There is no specific objective associated with these } \\
\text { achievements }\end{array}$ & $\begin{array}{l}\text { Understand the provisions and etiquette of engagement } \\
\text { and marriage. }\end{array}$ \\
\hline
\end{tabular}

The results in Table (No. 2) indicate that the expected outcomes from the first and seventh goals are not specified. On the other hand, the expected outcomes of students are in clarifying the concept of jurisprudence, identifying its sources, analyzing the concept of legal mandated governance, understanding the provisions and etiquette of engagement and marriage, and deducing the purposes of Islamic Sharia through the wisdom of the legislation. These achievements have not been assigned with specific objectives in the branch of Islamic jurisprudence.

The results also indicate a lack of agreement between the special goals and the expected achievements of students, which appear in the third, fourth, fifth, and sixth goals.

\section{RESULTS ANALYSIS AND DISCUSSION}

This study aims to analyze and criticize the objectives and content of the Islamic jurisprudence branch in the curriculum of religion and Islamic education for the secondary stage in Arab schools in Israel. In addition to evaluate its suitability to the Islamic education curriculum according to the Islamic philosophy of education, and its contribution to the preparation of contemporary Muslim women in the Arab society in Israel, and its inclusion of the associated issues and provisions.

It is clear from the results of the analysis of the branch of Islamic jurisprudence in the curriculum of religion and Islamic education for the secondary stage that it ignores most of the issues and rulings related to contemporary women. Its goals and contents focused on the field of worship, and on one of its manifestations, which is mostly the ritual appearance, as it revolved around the pillars of Islam represented in purity and prayer. fasting, zakat and Hajj, and these goals and contents are considered a repetition of what the student learned in the previous stages (elementary and preparatory), on the grounds that they are 
charged to know them and apply their rulings as they reach the age of being in charge of applying the Islamic rituals that coincides with the age of adolescence.

Al-Kilani (2005) stresses the necessity of including the worship branch in the Islamic education curriculum with content related to the ritual appearance, the social appearance, and the cosmic appearance. The ritual appearance represents the explanation of the rituals and practices to worship Allah. This requires familiarizing the female learners with the details of religious rituals and practices, and training them to perform them in the light of the related Islamic directives. This is what the Islamic jurisprudence branch contains in the Islamic education curriculum for the secondary stage.

As for the second aspect of worship is the social aspect that is linked to culture, values, customs and systems; requires introducing the educated women to the network of social relations, starting from their family circle and ending with their human circle. It also requires teaching them its practices, and studying the practices of others in the past and present; to find out its positive and negative results and fruits, and this is what the Islamic jurisprudence branch lacks in the Islamic education curriculum for the secondary stage. The results of the analysis showed that the curriculum did not include these goals and contents, and the results of this study are in agreement with the study (Al-Kilani, 2005), which indicated that Islam has become for many Muslims a spiritual relationship confined to the performance of ritual worship. Although it was and still is the one and only source for all aspects of life for Muslims. Therefore, this approach undoubtedly contributes to the preparation of the female learner whose devotional ritual practice is dominant, or the religious learner whose religiosity is focused on the ritual appearance only.

The results indicate that the Islamic jurisprudence branch in the curriculum of Islamic education for the secondary stage lacks, in its construction, contemporary jurisprudential issues and rulings that the student needs to know. This may cause her confusion and turmoil in dealing with various events and situations. It is built in the light of common jurisprudence issues and rulings, and does not touch the reality of student's life in society. Despite the necessity for the student to know the rulings related to purity, prayer, zakat, fasting and Hajj, she must know the rulings related to all the issues related to women, especially the emerging ones, in order not to fall into serious issues. This result is consistent with the study of Al-Rifai (2016), which indicated that the Book of Jurisprudence in the Kingdom of Saudi Arabia, that is taught in the secondary stage lacks contemporary issues that concern women.

The results of the study reveals that the issues related to engagement and marriage are decided within the optional topics. That means it is not necessary to teach these contents to female students in the secondary stage; bearing in mind that the secondary stage is one 
of the age stages in which girls must be qualified for issues and topics related to women. The girl should be familiar with all the affairs of her life, and this result agrees with the study (Özdoğru et a, 2002), in which the researchers pointed out the need to focus on women's roles in society and not limit them to household chores only. This result contradicts the study (Khawalda and Al-Tamimi, 2013); As its results shows a focus on the topics of engagement and marriage in more than one place in the Islamic education curriculum, mentioning engagement and marriage in the unit of the hadith and its sciences, and in the unit of Islamic jurisprudence, specifically those that related to women.

Based on these results, attention must be paid to rehabilitating women and familiarizing them with all their issues and provisions to prepare them for effective participation in the renaissance of our Arab society. This requires educating people in charge in the education system to re-design the curricula in general and the curriculum of religion and Islamic education in particular; to serve women's issues and improve their standard of life, given that, curricula have a major role in the process of social change. As it is one of the means that affects individuals' awareness, beliefs, values and customs.

The curriculum also is required to be taught by educators and qualified institutions that are able to understand the constants of religion and the current changes. That will help in strengthening the student's relationship with God Almighty, and introduce her to the issues of society and the problems it poses, by making her aware that Islamic jurisprudence is capable of facing developments in every era, because its principles and systems are valid for all times and places.

\section{CONCLUSION}

This study focuses on analyzing the content of the Islamic jurisprudence branch in the curriculum of religion and Islamic education for the secondary stage. It concludes that the Islamic jurisprudence branch needs to reconsider deciding its objectives and contents to suit the characteristics of the student's growth, so that it goes hand in hand with it, so that they do not feel the gap between what they live with and what they learn. Since it appears through the results, that Islamic jurisprudence in the curriculum of religion and Islamic education for the secondary stage has separated from the reality of the student, and neglected most of the issues and rulings in the areas of communications and personal status related to women. Therefore, it requires enrichment with such issues and provisions that the student is required to know, because after high school, she will go out to the real life, which requires sufficient knowledge of all related issues and rulings so that she can practice them in reality without conflicting with the rules and provisions of the Islamic religion. 


\section{References}

Ishtiwa, Fawzi. Abu Rizk, Ibtihal. Odeh, Muhammad (2011). Islamic Education Curricula and Teaching Methods, 1st Edition, Safaa Publishing House, Amman.

Al-Badayna, Yahya Marhil (2010). Building a Model to Evaluate the Islamic Education Curriculum, 1st Edition, Dar Safaa for Publishing and Distribution, Amman.

Al-Tamimi, Iman and Khawaldeh, Nasser (2013). Women's Issues in Islamic Education Textbooks for the Higher Basic Stage in Jordan, Journal of Educational Sciences Studies, 38 (3), 827-851.

Al-Jaafari, Riyadh Abdel-Rahman (2014). Evaluation of reading curricula at the secondary stage in the Kingdom of Saudi Arabia in the light of contemporary society issues, Specialized International Educational Journal, 3(11), 81-53.

Al-Khalidi, Nassima Mustafa Sadiq (2004). The Role of the School Curriculum in Empowering Jordanian Women, Ph.D. Thesis, University of Jordan, Amman.

Al-Rifai, Rabaa (2016). An analytical study of the content of jurisprudence books for the secondary stage in the Kingdom of Saudi Arabia and the extent to which it includes issues of women's jurisprudence, The Educational Journal, (43), 47-81.

Al Raqb, Akram (2015). A proposed conception for developing the content of the Islamic education curriculum for the secondary stage in Palestine in light of the results of educational research in master's and doctoral theses, $\mathrm{PhD}$ thesis, Cairo: Cairo University.

Sammak, Abdel Aziz Ramadan (2006). The history of Islamic legislation and its sources. Cairo: Arab Renaissance House.

Al-Salihi, Mohsen et al. (2009). The reality of the application of Islamic education in contemporary issues from the point of view of teachers in the State of Kuwait. Cairo: Education World Magazine, Issue 29, Year 10 (October). From pp. 15 to 66.

Abdel-Al, Asmahan (2011). The extent to which Islamic education books for the secondary stage include sexual education topics in the light of the Islamic conception of it, Master's Thesis, Gaza: The Islamic University.

Al-Asali, Alia et al. (2019). Analysis of the content of textbooks for grades one through nine in light of their gender sensitivity, Special Reports Series, Ramallah: The Independent Commission for Human Rights.

Al-Kilani, Majid Arsan (2006). The origins of Islamic education: a comparative study between the foundations of Islamic education and contemporary educational philosophies. 1st floor, Dar Al Qalam: Dubai.

Al-Kilani, Majid Arsan. (2005). An open letter to the Muslim girl in the era of globalization, 1st Edition, Dar Al-Qalam: Dubai.

Mualem, Waseem Abdel Rahman (2008). Educational methods to glorify the Sacred Land for secondary school students in the Holy Capital through extracurricular activities, Master's thesis, College of Education, Umm Al-Qura University.

Al-Nahlawi, Abdul Rahman (2010), The Origins of Islamic Education and Its Methods at Home, School and Society, 28th Edition, Dar Al-Fikr: Damascus.

Bowen, N (2004). A New Look at Woman's Roles During Selected Wars in U.S. History. A Thesis of Master, Louisiana State University. 
British Journal of Education

Vol.10, Issue 1, pp. 49-63, 2022

Online ISSN: 2054-636X (Online)

Print ISSN: 2054-6351(Print)

Özdoğru, A. Aksoy, G \& Gök, F (2002). Content Analysis for Gender Bias in Turkish Elementary School Textbooks, Boğaziçi University, Istanbul, Turkey.

Sahin, A (2018). Critical Issues in Islamic Education Studies: Rethinking Islamic and Western Liberal Secular Values of Education, Religions, (335), 1-29.

The Ministry of Education. (2016). Curriculum for teaching religion and Islamic education in Arab schools (grades: second-twelfth), Jerusalem: the educational secretariat. 